DOI https://doi.org/10.30525/978-9934-26-075-9-41

\title{
ПОРІВНЯЛЬНИЙ АНАЛІЗ КІЛЬКІСНОГО ВМІСТУ \\ ФЛАВОНОЇДІВ У ТРАВІ CALTHA PALUSTRIS, ЗАГОТОВЛЕНОЇ В 2018-2020 РОКАХ
}

\author{
Карпюк В. Р. \\ аспірант кафедри технологіі біологічно активних сполук, \\ фармаиії та біотехнології \\ Начіональний університет «Львівська політехніка» \\ Конечна Р. T. \\ кандидат фармацевтичних наук, \\ дочент кафедри технології біологічно активних сполук, \\ фармаиії та біотехнології. \\ Національний університет «Львівська політехніка»
}

Курка М. С.

кандидат хімічних наук,

дочент кафедри технології біологічно активних сполук, фармачії та біотехнології.

Національний університет «Львівська політехніка», м. Львів, Україна

Милянич А. О.

кандидат хімічних наук, дочент кафедри технології біологічно активних сполук, фармаиії та біотехнологіі Національний університет «Львівська політехніка»

\section{Хоменко О. I.}

кандидат хімічних наук, асистент кафедри фармацевтичної хімії, фармакогнозії і ботаніки з ресурсовознавством лікарських рослин ТзОВ «Львівський медичний інститут» м. Львів, Украӥна

Сьогодні світова фармацевтична промисловість, широко використовує рослинну сировину, яка $є$ основою для створення лікарських засобів. Велика кількість препаратів, що виробляються в світі, мають 
в своєму складі природні інгредієнти рослинного походження. Попит на фітопрепарати збільшується, тому актуальним завданням фармацевтичної науки є впровадження в практику нових видів лікарських рослин, які здавна відомі своїми цілющими властивостями, проте ще не достатньо вивчені.

Флавоноїди, група природних речовин із змінною фенольною структурою, містяться у представників родин: Бобові, Айстрові, Розові, Губоцвіти, Жовтецеві та інші. В даний час флавоноїди розглядаються як незамінний компонент у різних нутрицевтичних, фармацевтичних, лікарських та косметичних засобах. Це пояснюється їх антиоксидантними, протизапальними, антимутагенними та антиканцерогенними властивостями [1].

Лікарські рослини, представники родини Жовтецеві (Ranunculaceae), що здавна використовуються в медицині, $є$ джерелом цінних біологічно активних сполук [2]. Яскравим представником таких рослин $\epsilon$ Калюжниця болотна (Caltha palustris). Рослина здавна застосовується в народній медицині різних країн і проявляє широкий спектр лікувальних властивостей.

Caltha palustris містить біологічно активні речовини як первинного, так і вторинного синтезу. До ії складу входять алкалоїди, сапоніни, $\gamma$ лактони: протоанемонін, анемонін, дубильні речовини, феноли та аскорбінова кислота [3]. Як лікарську рослинну сировину використовують траву Caltha palustris, яку заготовляють, сушать та стандартизують за вимогами Державної фармакопеї України [4].

Метою роботи було провести порівняльний аналіз кількісного вмісту флавоноїдів у траві Caltha palustris заготовленої в екологічно чистих районах західної України у 2018, 2019 та 2020 роках.

Сировину Caltha palustris збирали з природніх місць зростання у Волинській області у 2018, 2019, 2020 роках, зрізаючи надземну частину рослини. Сушили, стандартизували та зберігали в сухому місці, окремо від іншої сировини.

Об'єктами дослідження були зразки трави Caltha palustris з різним терміном зберігання - 1 рік, 2 та 3 роки відповідно. Досліджувані зразки трави подрібнювали до розміру частинок 2-3 мм.

Екстракти Caltha palustris одержували методом мацерації. Як екстрагент використовували етанол в концентраціях 20\% (об/об) (екстракт ЕК1), 40\% (об/об) (екстракт ЕК2), 70\% (об/об) (екстракт ЕК3) та $90 \%$ (об/об) (екстракт ЕК4).

Кількісний вміст флавоноїдів визначали спектрофотометричним методом за реакцією комплексоутворення $3 \mathrm{AlCl}_{3} 3$ певними модифікаціями. Досліджували зразки при кімнатній температурі. 
Оптичну густину вимірювали при довжині хвилі 520 нм на спектрофотометрі Specord M 40.Дослідження проводили тричі. Як стандарт використано кверцетин. [5,6].

Результати виражали у мг кверцетину $(\mathrm{QE})$ на грам сухої сировини (трави Caltha palustris), використовуючи рівняння, отримане 3 калібрувальної кривої. Дані досліджень представлено в Таблиці 1.

Таблиця 1

Кількісний вміст флавоноїдів у досліджуваних екстрактах

\begin{tabular}{|c|c|c|c|c|c|c|}
\hline $\begin{array}{c}\text { Об’єкт } \\
\text { дослідження }\end{array}$ & \multicolumn{6}{|c|}{$\begin{array}{c}\text { Сума флавоноїдів в перерахунку } \\
\text { на кверцетин, мг QE / г, n=3 }\end{array}$} \\
\hline EK1 & \multirow{4}{*}{ 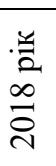 } & $1,035 \pm 0,02$ & \multirow{4}{*}{ 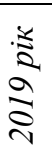 } & $5,8 \pm 0,02$ & \multirow{4}{*}{ 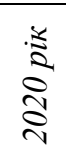 } & $11,7 \pm 0,01$ \\
\hline EK2 & & $1,18 \pm 0,01$ & & $6,35 \pm 0,04$ & & $12,6 \pm 0,02$ \\
\hline EK3 & & $2,3 \pm 0,02$ & & $10,07 \pm 0,02$ & & $19,85 \pm 0,03$ \\
\hline EK4 & & $5,05 \pm 0,03$ & & $6,07 \pm 0,01$ & & $8,5 \pm 0,02$ \\
\hline
\end{tabular}

Встановлено, що максимальний вміст флавоноїдів спостерігався у досліджуваних екстрактах одержаних 3 трави Caltha palustris, заготовленої у 2020 році з терміном зберігання 1 рік. Вміст флавоноїдів у екстрактах одержаних з трави Caltha palustris заготовленої у 2018 році 3 терміном зберігання 3 роки був мінімальним у порівнянні з вмістом у інших екстрактах. Це свідчить про те, що при тривалому зберіганні вміст біологічно-активних компонентів, зокрема флавоноїдів, зменшується і відповідно якість лікарської лікарської рослинної сировини погіршується.

Методом спектрофотометрії визначено кількісний вміст флавоноїдів у екстрактах трави Caltha palustris. Завдяки отриманим результатам, можемо оцінити зміну кількісного вмісту флавоноїдів у сировині Caltha palustris, з різним терміном зберігання.

\section{Література:}

1. Flavonoids: an overview. / A. N. Panche, A. D. Diwan, S. R. Chandra/ Published online. Dec 2016. № 29. PП.47. Doi: 10.1017/jns.2016.41

2. Лях В.Р. , Конечна Р.Т. Прикладні аспекти застосування лікарських рослин родини RANUNCULACEAE в етномедицині та фармаціï. Lublin, Poland,2020. 202-217c.

3. V. Liakh, R. Konechna, A. Mylyanych, L. Zhurakhivska, I. Hubytska, V. Novikov. CALTHA PALUSTRIS. ANALYTICAL OVERVIEW. Scientific Journal «ScienceRise: Pharmaceutical Science» №2 (24)2020. C. 51-56. 164 
4. Державна Фармакопея України / Державне підприємство «Український науковий фармакопейний центр якості лікарських засобів». - 2-е вид. - Доповнення 4. - Харків: Державне підприємство «Український науковий фармакопейний центр якості лікарських засобів», 2020. 105 с.

5. Do Q.D. Effect of extraction solvent on total phenol content, total flavonoid content, and antioxidant activity of Limnophila aromatica / Q.D. Do, A.E. Angkawijaya, P.L. Tran-Nguyen [et al] // Journal of Food and Drug Analysis. - 2014. - № 22. - P. 296-302.

6. Determination of total phenolic content, total flavonoid content, and antimutagenic activity of ethanol extract nanoparticles of rhaphidophora pinnata (L.f) schott leaves / Sumaiyah, Masfria and A. Dalimunthe // Rasayan Journal of Chemistry. - 2018. - № 2. - P. 505-510.

DOI https://doi.org/10.30525/978-9934-26-075-9-42

\title{
ПІДХОДИ ДО ВІДНОВЛЕННЯ ПОРУШЕНОЇ СМАКОВОЇ ТА НЮХОВОЇ ЧУТЛИВОСТІ ВНАСЛІДОК IНФІКУВАННЯ SARS-COV-2
}

\author{
Луцак I. B. \\ кандидат фармачевтичних наук, \\ викладач фармачевтичних дисциплін \\ Житомирський базовий фармачевтичний фаховий коледж \\ Косяченко Н. М. \\ кандидат фармацевтичних наук, \\ викладач фармачевтичних дисциплін \\ Житомирський базовий фармачевтичний фаховий коледж \\ Зубрицька Т. P. \\ викладач фармачевтичних дисциплін \\ Житомирський базовий фармацевтичний фаховий коледж \\ м. Житомир, Украӥна
}

Актуальність. 3 активним поширенням коронавірусної інфекції, погіршення смакового і нюхового сприйняття привернуло увагу як науковців так і пацієнтів в усьому світі. Очевидним постав зв'язок між вказаними порушеннями і COVID, оскільки втрату здатності відчувати 